\title{
Analysis Activity of Elephantopus scaber Leaves Extract Against Quantitative Changes of Lymphocytes Cells in BALB/c Mice After Induction of DMBA and Estrogen
}

\author{
Lailiyavina Rochmatika ${ }^{1}$, Sri Widyarti ${ }^{2}$, Muhammad Sasmito Djati2* \\ ${ }^{1}$ Master Program of Biology, Faculty of Mathematics and Natural Sciences, University of Brawijaya, Malang, Indonesia \\ ${ }^{2}$ Department of Biology, Faculty of Mathematics and Natural Sciences, University of Brawijaya, Malang, Indonesia
}

\begin{abstract}
The carcinogenic compounds such as DMBA known for having the ability to promote the DNA damage that affects the growth regulator genes. Therefore, uncontrolled cell growth will occur and change the immune system. Elephantopus scaber extract is considered as an alternative way of handling breast cancer since it capable to affect the work of the immune system. Hence, this study aims to determine the effect of $E$. scaber extract on quantitative changes of CD4 $4^{+}$, $\mathrm{CD}^{+} \mathrm{T}$ cells and proinflammatory cytokines $\mathrm{CD} 4^{+} \mathrm{IFN}-\gamma^{+}$and $\mathrm{CD} 4^{+} \mathrm{TNF}-\alpha^{+}$after induction of DMBA and estrogen. In vivo experiments were carried out by using 5-6 weeks old of female mice BALB/c strain. The extract of $E$. scaber leaf powder was obtained from Material Medica Batu, Malang. The experimental animals were divided into five groups such as negative control group (K-), positive control group $(\mathrm{K}+)$, mice treated with $E$. scaber extract for a week (group 1), mice treated with E. scaber extract for 2 weeks (group 2), and mice treated with E. scaber extract for 3 weeks (group 3). Induction of DMBA and estrogen was conducted by injection of DMBA (7.12 dimetylbenz $(\alpha)$ anthracene) 0.56 mg.kgBW ${ }^{-1}$ and estradiol hormone $0.0504 \mathrm{mg}^{\mathrm{kgBW}}{ }^{-1}$. Mice were treated with E. scaber extract with a dose of 50 mg.kgBW ${ }^{-1}$. Lymphocytes were isolated from spleen and observed the $\mathrm{CD}^{+}, \mathrm{CD}^{+} \mathrm{T}$ cells and proinflammatory cytokines CD4 $4^{+}$IFN $-\gamma^{+}$and CD4 ${ }^{+}$TNF- $\alpha^{+}$T cells through flow cytometry analysis. One-way ANOVA $(p<0.05)$ and SPSS were used to analyze this data. The results showed that the induction of DMBA and estradiol hormone affected mice fur loss. It also decreased the immune system by lowering the number of CD4 and CD8 T cells. However, E. scaber extracts increased the number of pro-inflammatory cytokines TNF- $\alpha$. Furthermore, the DMBA and estradiol induction also promoted the number of CD4 ${ }^{+} \mathrm{IFN}-\gamma^{+}$in the first week, but decreased the number of CD4 ${ }^{+} \mathrm{IFN}-\gamma^{+}$at weeks 2 and 3 , then increase the number of $\mathrm{CD}^{+} \mathrm{IFN}-\gamma^{+}$. So, the treatment of $E$. scaber extracts demonstrated the ability to restore the homeostasis of the immune system in the first and second weeks.
\end{abstract}

Keywords: $\mathrm{CD}^{+}, \mathrm{CD}^{+}, \mathrm{DMBA}$, estrogen, E.scaber, IFN- $\gamma^{+}, \mathrm{TNF}-\alpha^{+}$

\section{INTRODUCTION}

DMBA compounds $(7.12$ dimetylbenz $(\alpha)$ anthracene) are carcinogenic substances that have a higher and more stable potential for creating cancer models in experimental animals. DMBA compounds induced in the body will be metabolized in the liver by cytochrome P450 CYP1A1 or CYP1B1 and $\mathrm{mEH}$ (microsomal epoxides hydrolase) in peripheral tissues forming covalent bonds to DMBA 3,4 diol-1,2 epoxide (DMBA-DE) to DNA adduct form [1].

Among various kind of cancer, breast cancer is being the most common cancer suffered by women [1]. According to the data, breast cancer is the second most common disease after lung cancer in Indonesia [2].

The presence of cancer will cause a change in the immune system. Commonly, cancer cells

\footnotetext{
*Correspondence address:

Muhammad Sasmito Djati

E-mail : msdjati@ub.ac.id

Address : Dept. Biology, University of Brawijaya, Veteran Malang, Malang 65145.
}

cannot be recognized by the immune system, because of cytokine production that prevents the immune response such as the TGF- $\beta$. The increased level of TGF- $\beta$ cytokines will inhibit the work of CD4 and CD8 T cells [3]. Those cytokines will be needed for the development of CD8 + cytotoxic cells to become effector cells [4].

Immune cells that reside around the cancer cells have been known to kill cancer cells around them. Some lymphocyte subpopulations, both T helper lymphocytes and cytotoxic $T$ play a role in eliminating tumor antigens. Cells that contain tumor antigens will express their antigens together with class I MHC molecules that form a complex through TCR (T cell receptor) from cytotoxic T cells [4].

One of the alternative treatments is the utilization of herbal medicines. Cancer prevention through medicinal plants is based on the chemopreventive compounds that can inhibit the carcinogen process so that it can prevent the cancer growth [5]. Flavonoids and isoflavonoids had widely known to inhibit the process of carcinogenesis [6]. 
Elephantopus scaber or Tapak Liman is one of herbal that has the potential ability to be used as herbal medicine. Tapak Liman plant containing several compounds such as flavonoids, alkaloids, tannins, phenols, steroids, terpenoids, saponins, isodeoxyelephantopin, and also deoxyelephantopin. Deoxyelephantopin and isodeoxyelephantopin have been reported to have the ability to induce apoptosis and inhibit the activation of $\mathrm{Nf}$ $\mathrm{kB}$ in cancer cells $[7,8]$.

Elephantopus scaber extract has a function as an anti-inflammatory, analgesic, antioxidant, and antimicrobials. Flavonoids can prevent tumorigenesis through several mechanisms, namely cytochrome P450 isoenzyme activity, induction of glutathione S-transferase enzyme (GST), and oxidative inhibition. Isoenzyme activity inhibits cytochrome P450 CYP1A1 and CYP1A1 or DMBA, causing non-reactive carcinogens [1,9]. Therefore, this study aims to determine the effect of Elephantopus scaber extract on breast cancer based on the immune system mechanism. It is supported by previous study, which stated that $E$. scaber had an ability as an anti-cancer agent [10]. This study used breast cancer mice model generated by DMBA and estrogen hormone induction.

\section{MATERIAL AND METHOD}

Twenty-seven female albino mice (BALB/C) with 4-5 weeks old were obtained from the Malang Murine Farm, Singosari. Mice acclimatized for seven days before experiments. Then, they were randomly divided into five groups, including a control group, DMBA-treated group, extract-treated group for week treatment, extract-treated group for 2 weeks of treatment, and extract-treated group for 3 weeks treatment. This research was approved by the institutional ethical committee of Brawijaya University, No.648-KEP-UB, 8 ${ }^{\text {th }}$ December 2016.

\section{Extraction of Tapak liman (Elephantopus scaber)}

Powder of E. scaber leaf obtained from Material Medica Batu, Malang. Powder of Elephantopus scaber macerated with ethanol $50 \%$ by comparison bulbs: ethanol $50 \%=1: 10$ at room temperature during $5 \times 24$ hours, and stirred 3 times a day until all the components completely extracted. Thereafter, the ethanol extract filtered with a filter cloth and placed into a glass jar. The rest of the filtering material soaked again with ethanol $50 \%$ for 48 hours. Then, the material filtered by using filter cloth. The result of extraction evaporated to remove the ethanol content by using a water bath at $50^{\circ} \mathrm{C}$ and vacuum pump evaporator. Crude extracts were collected in the paste form, dark brown, and has a distinctive smell. Then, it placed in jar lid films and stored in a refrigerator at $4^{\circ} \mathrm{C}$. Extract of $E$. scaber dose $50 \mathrm{mg} . \mathrm{kg}^{-1} \mathrm{BW}$ prepared for an experiment by dissolved it in warm water to make a stock solution.

\section{Injection of DMBA and Estradiol}

Five weeks old mice injected with DMBA (7,12-Dimethylbenz( $\alpha$ )antrasena) at the rate of $0.56 \mathrm{mg} . \mathrm{kg}^{-1}$ BW. It was administered by subcutan (s.c) injection with a volume $3 \mu \mathrm{L} . \mathrm{g}^{-1}$ BW. Furthermore, mice were injected with estradiol at the rate of $0.0504 \mathrm{mg} \cdot \mathrm{kg}^{-1} \mathrm{BW}$. The injection of DMBA and estradiol conducted weekly. Estradiol injection addressed to accelerate cancer growth.

\section{Research Design}

This study carried out by using five groups of mice consisting of negative control groups (K-), positive control $(\mathrm{K}+)$, and DMBA-estradiolinduced treatment groups then given extract of E. scaber. The treatment group consisted of three groups, namely the treatment group 1 week, which carried out with oral administration of extract E. scaber for a week. The second group is with oral administration of the extract of $E$. scaber for two weeks, and the third group for three weeks. Treatment was conducted by oral administration after mice injected with DMBA and estradiol for eight weeks and evaluated as positive breast cancer.

\section{Lymphocyte Cell Isolation}

Mice were sacrificed and dissected to isolate the spleen and liver organ. The obtained organ was washed and squeezed with PBS solution in a separate dish until all the cells become soluble. Then, the pellet suspension was filtered and put into a $15 \mathrm{~mL}$ polypropylene tube until the volume reached $10 \mathrm{~mL}$. The suspension centrifuged at $2500 \mathrm{rpm}$ at $10^{\circ} \mathrm{C}$ for 5 minutes. The supernatant discarded, and the pellet resuspended in $1 \mathrm{~mL}$ of PBS.

\section{Preparation and Flowcytometry Analysis}

The pellet suspension from each sample about $50 \mu \mathrm{L}$ inserted into a sterile microtube containing $500 \mu \mathrm{L}$ of PBS. The suspension was centrifuged with $2500 \mathrm{rpm}$ at $10^{\circ} \mathrm{C}$ for 5 minutes. Extracellular staining carried out by adding $50 \mu \mathrm{L}$ of monoclonal antibody (Fluorescein isothiocyanate (FITC) - conjugated CD4 antimouse rat (BiolegendTM), Phycoerythrin (PE) Clocked anti-mouse CD8 rat (BiolegendTM), then incubated at $4^{\circ} \mathrm{C}$ for 20 minutes. Furthermore, it 
was added with $300 \mu \mathrm{L}$ PBS and transferred to the Cuvet. The intracellular staining was conducted by adding $50 \mu \mathrm{L}$ of cytofix-cytoferm (SIGMATM) to the pellet suspension and incubated at $4^{\circ} \mathrm{C}$ for 20 minutes. After incubation, $500 \mu \mathrm{L}$ of washperm (SIGMATM) added and centrifuged with $2500 \mathrm{rpm}$ at $10^{\circ} \mathrm{C}$ for 5 minutes. Pellets were collected and stained with intracellular antibodies (TNF- $\alpha$ anti-mouse rat (BiolegendTM) and PE - IFN- $\gamma$ (BiolegendTM) anti-mouse conjugate) then incubated at $4^{\circ} \mathrm{C}$ for 20 minutes. Moreover, $300 \mu \mathrm{L}$ PBS added and inserted into the cuvet of flow cytometry. In detail, the total number of cells was selected so that it could be detected by the antibody label. The obtained results were processed by BD cell quest ProTM software.

\section{Statistical Analysis}

The obtained data were analyzed by the CellQuest software and calculated by statistical analysis of ANOVA with $P<0.05$. The analysis data were conducted by using SPSS 16.0 for the Windows program. The data were generated in the form of a relative number of cells tested statistically by the normality test and variance homogeneity test. Then, the normal and homogeneous tests carried out for further analysis by using Two-way ANOVA with $\alpha=0.05$. Furthermore, it tested with the Tukey HSD test (High Significant Difference).

\section{RESULT AND DISCUSSION}

\section{Analysis the Number of $\mathrm{CD} 4^{+}$}

The $\mathrm{CD}^{+} \mathrm{T}$ cells from spleen, which analyzed by using flowcytometry showed that the average length of the extract administration significantly affected each treatment group. The p-value $<0.05$ means that the average number of $\mathrm{CD}^{+} \mathrm{T}$ cells in each treatment is significantly different. The interaction between treatment and duration of administration of extracts showed a p-value $<0.05$. It means that treatment and the duration of administration of extracts have an interaction.

The analysis results of $\mathrm{CD}^{+} \mathrm{T}$ cells by using flowcytometry after DMBA and estradiol induction showed that there was a decrease in the positive control group (carcinogen induction)
(Table 1). It occurred significantly $(p<0.05)$ on a weekly basis. The cell number in the first, second, and the third week was $17.34 \%, 10.55 \%, 4.34 \%$, respectively.

In the first week, the immune system recognized the presence of antigens so that the immune system in the body responded by producing effector cells such as $\mathrm{CD}^{+} \mathrm{T}$ cells. Moreover, the low number of cells in the second and third weeks could be caused by the immune system in the body started to be recovered by itself or it could be explained that the administration of DMBA has no effect on mice.

It means that the body's response decreases or the body are in the homeostatic state. According to the previous study, the number of $\mathrm{CD}^{+}$in $\mathrm{T}$ cells in breast cancer subjects was significantly decreased $(p<0.05)$ [11]. In addition, the number of $\mathrm{CD}^{+} \mathrm{T}$ cells in the final stage decreased as the previous stage. $\mathrm{CD} 4^{+} \mathrm{T}$ cells play an important as an antitumor function by producing IFN- $\gamma$ and TNF- $\alpha$ cells to activate cytotoxic T cells. Activated T cells will activate the cytotoxic T cells, macrophages, and NK cells to prevent the growth of tumors through the lysis process.

The relative number of $\mathrm{CD}^{+}$in the DMBAEstradiol induced cancer group had a lower number compared to the normal group. It could be caused by the cancer condition, which excreted of several cytokines such as TGF-beta. That cytokines are immunosuppressive cytokines types. It will promote suppression of effector $T$ cells so that $\mathrm{CD}^{+}$acts as an immunocompetent of IFN- $\gamma$ cytokine producer and cytotoxic cells to destroy the tumor cells [3].

The herbal treatment for the cancer mice model can reduce the number of $\mathrm{CD} 4^{+} \mathrm{T}$ cells. It presented by the relative number of $\mathrm{CD} 4^{+}$cells in the first week to the third week of $7.23 \%, 2.54 \%$, and $5.59 \%$, respectively (Fig. 1). The E. scaber extract administration for three weeks did not show a significant result compared to the extract administration for two weeks. Therefore, the administration of extract for three weeks did not affect $C D 4^{+} \mathrm{T}$ cells.

Table 1. Relative number of $\mathrm{CD} 4^{+}$and $\mathrm{CD} 8^{+} \mathrm{T}$ cells from spleen organs

\begin{tabular}{llll|ccc}
\hline & \multicolumn{3}{c|}{ CD4+ (\%) } & \multicolumn{3}{c}{ CD8+ (\%) } \\
\cline { 2 - 7 } & $1^{\text {st }}$ week & $2^{\text {nd }}$ week & $3^{\text {rd }}$ week & $1^{\text {st }}$ week & $2^{\text {nd }}$ week & $3^{\text {rd }}$ week \\
\hline K- & $20.75^{\text {de }}$ & $21.91^{\mathrm{e}}$ & $21.21^{\text {de }}$ & $9.96^{\mathrm{b}}$ & $13.11^{\mathrm{c}}$ & $16.68^{\mathrm{d}}$ \\
$\mathrm{K}+$ & $17.34^{\mathrm{d}}$ & $10.55^{\mathrm{c}}$ & $4.34^{\mathrm{ab}}$ & $17.03^{\mathrm{d}}$ & $9.76^{\mathrm{b}}$ & $8.5^{\mathrm{b}}$ \\
$\mathrm{P}$ & $7.23^{\mathrm{bc}}$ & $2.54^{\mathrm{a}}$ & $5.59^{\mathrm{ab}}$ & $9.31^{\mathrm{b}}$ & $1.3^{\mathrm{a}}$ & $10.19^{\mathrm{b}}$ \\
\hline
\end{tabular}

Notes: $\mathrm{K}$ - = healthy mice, $\mathrm{K}+=$ induced $\mathrm{DMBA}$ and Estradiol mice, $\mathrm{P}=$ Induced $\mathrm{DMBA}$ and Estradiol treated and administration of $E$. scaber extract $50 \mathrm{mg} \cdot \mathrm{kg}^{-1} \mathrm{BW}$. 


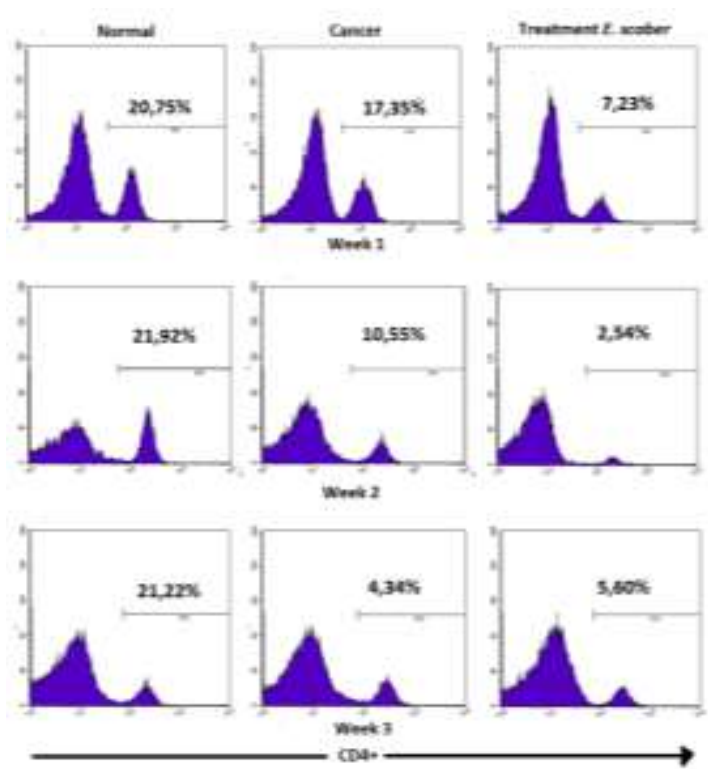

Figure 1. Percentage of the relative number of $\mathrm{CD}^{+} \mathrm{T}$ cell at the spleen organ.

Elephantopus scaber extract contains several compounds such as flavonoids, alkaloid saponins, tannins, phenols, steroids, isodeoxyelephantopin, terpenoids, and deoxyelephantopin [7]. Cheeke [12] stated that saponin and flavonoid compounds had a function as natural immunomodulators. Saponins and flavonoids can enhance the immune responses, especially for increasing the number of immunocompetent cells such as $\mathrm{CD} 4^{+} \mathrm{T}$ cells.

However, this is not comparable with the obtained results in breast cancer case after administration of DMBA and estradiol. It showed that the compounds of $E$. scaber extract have not been able to increase the number of $\mathrm{CD}^{+} \mathrm{T}$ cells in mice after DMBA and estradiol administration. However, according to the previous study, a high dose of $E$. Scaber leaf extract can reduce the number of $\mathrm{CD}^{+} \mathrm{T}$ cells [13].

The importance of CD4 T cells as antitumor immunity can be emphasized in several aspects. First, the initial idea that CD4 T cells provide assistance to induce and maintain a specific response to CD8 cytotoxic T cells. Second, CD4 T cells can develop and maintain CD8 memory $T$ cells. Third, the tumor rejected by cytotoxic effects of CD4 $\mathrm{T}$ cells, regulation of $\mathrm{MHC}$ molecules, antiangiogenesis, and tumor lysis induction [14]. So in this case, the tumor formed rapidly than the immune system in the body.

\section{Analysis the Number of CD8+ T Cells}

The analysis results of CD8 $\mathrm{T}$ cell from spleen which analyzed by using flowcytometry showed that the average length of administration of the extract significantly affected each treatment group. In addition, it appears that $p$-value $(<0.05)$ means that the average number of CD8 T cells in each treatment was significantly different. The interaction between treatment and duration of administration of extracts showed $p<0.05$, which means that there was an interaction.

Based on the $\mathrm{CD}^{+} \mathrm{T}$ cell analysis from spleen (Table 1), it showed that the DMBA-induced group of mice and estradiol (positive control) had a relative cell number of $17.03 \%$ in the first week, $9.76 \%$ on the second week, and $8.50 \%$ on the third week. The relative number of $\mathrm{CD}^{+} \mathrm{T}$ cells increased on the first week compared to healthy mice (negative controls). It showed a significant increase compared to healthy mice or negative controls.

However, the relative number of $\mathrm{CD}^{+} \mathrm{T}$ cells at weeks 2 and 3 decreased. It means that $C D 8^{+} T$ cells, which had a function as cytotoxic $T$ cells, were formed in the first week to fight tumor cells and regulate the cellular and humoral immune system, such as activating Th2 lymphocytes by secreting cytokines that induce $B$ lymphocytes to become plasma cells [3]. The decreased number of $\mathrm{CD}^{+} \mathrm{T}$ cells at week 3 demonstrated that there was a process of homeostasis in the body in neutralizing the presence of foreign objects that enter the body.

$\mathrm{CD}^{+} \mathrm{T}$ cells have special functions in lytic functions, and they also has the ability to express MHC class I. Therefore, it is believed that $C D 8^{+} \mathrm{T}$ cells are the main effector cells which responsible for eliminating tumor cells. However, tumorreactive $\mathrm{CD}^{+}{ }^{+} \mathrm{T}$ cells can develop cytotoxic activity and mediate tumor rejection through the introduction of class II MHC antigens $[15,16]$. Cells that contain tumor antigens will bind to the $\mathrm{MHC}$ I. Then, it will form a complex through TCR (T Cell Receptor) from CD8 T cells (cytotoxic) so that CD8 T cells are activated and play a role in cell lysis $[8,17]$. According to the previous study, the number of CD8 $T$ cells in breast cancer subjects was also significantly decreased ( $p$ $<0.05)$. In addition, the number of CD8 T cells in the final stage decreased compared to the previous stage.

The mice group induced by DMBA and estradiol also treated with $E$. scaber extract. The result showed a significant decrease $(p<0.05)$ compared to the cancer group (positive control) in the first week and the second week. Previous studies exhibited that the effects of the Elephantopus scaber at doses of $0.5 \mathrm{~g} . \mathrm{g}^{-1} \mathrm{BW}$ and 
1.0 g. $\mathrm{g}^{-1} \mathrm{BW}$ could increase the CD8 T cells number, but decrease the number of CD4 and CD8 T cells at a dose of $2.0 \mathrm{~g} \cdot \mathrm{g}^{-1} \mathrm{BW}$. The lower doses could stimulate the proliferation of T cells, while at high doses, it could prevent the $\mathrm{T}$ cell proliferation [19].

The number of CD4 and CD8 T cells in this study showed that the $E$. scaber extract played a role as immunosuppressants of $\mathrm{CD}^{+}$and $\mathrm{CD}^{+} \mathrm{T}$ cells in the second week. It is due to the content of lupeol and flavonoids, which act as an antiinflammatory agent. Previous research has also shown that the effects of herbs can stimulate or otherwise suppress immunity $[19,20]$. The low number of $\mathrm{CD}^{+} \mathrm{T}$ cells in mice after administrated by $E$. scaber extract probably caused by the content of isodeoxyelephantopin on Tapak Liman leaves [8]. It is known to increase the number of regulatory $T$ cells for suppressing excessive immuno-competent cells inside the body.

The number of $\mathrm{CD}^{+} \mathrm{T}$ cells and $\mathrm{CD} 8^{+} \mathrm{T}$ cells decreased due to the activation of $\mathrm{CD}^{+}$cells which developed into Th1 and Th2 cells [13]. In addition, the response of $\mathrm{CD}^{+} \mathrm{T}$ cells will increase the pro-inflammatory cytokines released by $\mathrm{CD}^{+} \mathrm{T}$ cells. Furthermore, it also has a function to activate the immunocompetent cells such as IFN $\gamma$, which play a role in increasing the expression of $\mathrm{MHC}$ I so that it can be recognized by $\mathrm{CD}^{+} \mathrm{T}$ cells. Moreover, the $\mathrm{CD}^{+} \mathrm{T}$ cells naive can be activated into $T$ cells effector. However, the decreased number of $C D 4^{+} T$ cells will cause $T$ cells naive to be unable to differentiate into effector $\mathrm{CD} 8^{+} \mathrm{T}$ cells optimally.

CD8 $T$ cells are the essential mediator in the body's immunity system to several pathogens, including viruses, intracellular parasites, and bacteria. It also has a function as immune protection against cancer. The optimal induction response of CD8 T cells is very important for our defense against infective disease or cancer. Cytotoxic T lymphocytes (CTLs) play a major role in the rejection of immunogenic tumors. Cellular immune responses are the process of presenting protein antigen-presenting cells (APCs) and current antigenic peptide fragments through the MHC II complex to CD4 T cells. Activated CD4 cells will help the effector cells through cytokine production $[17,18]$.

The results of the number of CD4 and CD8 T cells have almost the same number in cancer cases. The total number of CD4 T cells in the first week was about $17.34 \%$, while CD8 T cells were
$17.03 \%$. The CD4 cell number in week 2 was $10.55 \%$, while in CD8, it was $9.76 \%$. Whilst, the CD4 number at week 3 was $4.34 \%$, and the CD8 cells were $8.50 \%$ (Fig. 2).

The CD4 T cells play an important role in facilitating the initial activation and development of CD8 T cells. During the CD8 phase priming, the $T$ cells are activating CD4 T cells so that it can help to activate the CDL CTL. The CD4 T cells regulate the antitumor $C D L C T L$ response through direct cell interaction and IL-2 stimulation. CD4 T cells can directly help activate CD8 cells through CD40-CD154 interactions $[21,22,23]$.

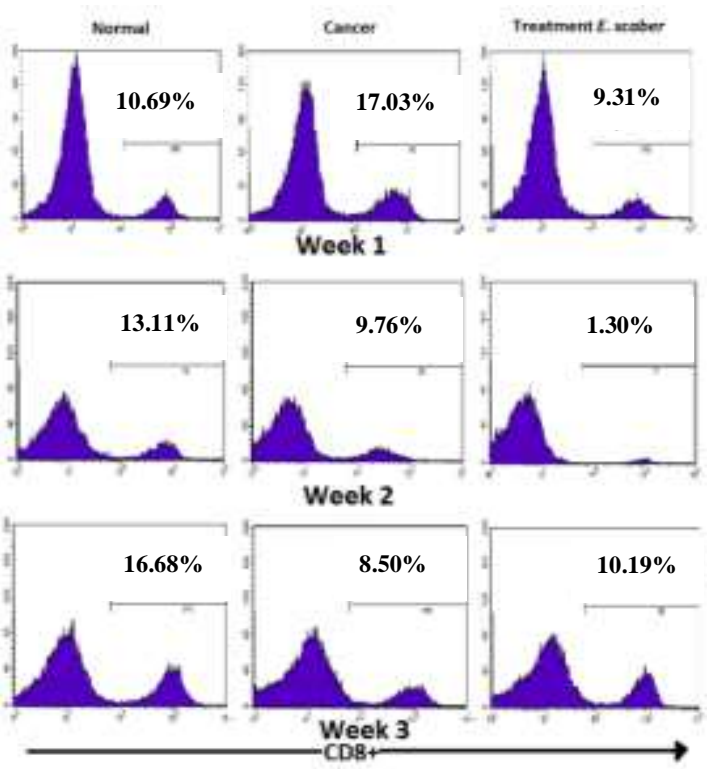

Figure 2. Percentage of the relative number of $\mathrm{CD}^{+} \mathrm{T}$ cell at the spleen organ.

\section{Analysis the Number of CD4 ${ }^{+}$TNF- $\alpha^{+}$T Cells}

TNF- $\alpha$ is a pleiotropic cytokine produced by various nucleated cells in the body. TNF- $\alpha$ is a pro-inflammatory agent that will regulate macrophages to respond to trauma, infection, and cell stress, such as tumors. However, the main function of TNF- $\alpha$ is as a mediator in producing other proinflammatory cytokines such as IL-1 and IL-6 [24].

Based on the results of this study, the relative number of cells in the normal mice group (K-) was lower than the DMBA and estradiol induction group. However, the treatment group treated by $E$. scaber extract has a significant difference as compared to the normal group (K-). The group that had been induced by DMBA and estradiol $(\mathrm{K}+)$ had a total number of $3.06 \%$, and it was significantly different from the normal group $2.09 \%$. It means that the immune system performed self-recovery after exposure to the DMBA and estradiol. 

of DMBA and Estrogen (Rochmatika et al)

Table 2. Relative number of $\mathrm{CD} 4^{+} \mathrm{TNFa}^{+}$and $\mathrm{CD} 4^{+} \mathrm{IFNg}^{+} \mathrm{T}$ cells from spleen organs (\%)

\begin{tabular}{lccc|ccc}
\hline & \multicolumn{3}{c|}{ CD4+TNFa+ (\%) } & \multicolumn{3}{c}{ CD4+IFNY+ (\%) } \\
\cline { 2 - 7 } & $1^{\text {st }}$ week & $2^{\text {nd }}$ week & $3^{\text {rd }}$ week & $1^{\text {st }}$ week & $2^{\text {nd }}$ week & $3^{\text {rd }}$ week \\
\hline $\mathrm{K}-$ & $1.58^{\mathrm{a}}$ & $3.34^{\mathrm{bc}}$ & $1.35^{\mathrm{a}}$ & $2.67^{\mathrm{ab}}$ & $4.03^{\mathrm{bc}}$ & $4.62^{\mathrm{bc}}$ \\
$\mathrm{K}+$ & $2.77^{\mathrm{ab}}$ & $1.19^{\mathrm{a}}$ & $5.19^{\mathrm{de}}$ & $5.99^{\mathrm{c}}$ & $1.126^{\mathrm{a}}$ & $2.20^{\mathrm{ab}}$ \\
$\mathrm{P}$ & $6.69^{\mathrm{e}}$ & $6.13^{\mathrm{de}}$ & $4.59^{\text {cd }}$ & $15.15^{\mathrm{e}}$ & $12.35^{\mathrm{d}}$ & $2.54^{\mathrm{ab}}$ \\
\hline
\end{tabular}

Notes: $\mathrm{K}-=$ healthy mice, $\mathrm{K}+=$ induced $\mathrm{DMBA}$ and Estradiol mice, $\mathrm{P}=$ Induced DMBA and Estradiol treated and administration of E. scaber extract $50 \mathrm{mg} \cdot \mathrm{kg}^{-1} \mathrm{BW}$.

The treatment of E.scaber extract in mice exposed to DMBA and estradiol showed a significant difference ( $p<0.05$ ) about $5.81 \%$ compared to the normal group and positive controls (exposure to DMBA and estradiol). This high number means that the active ingredient in E. scaber extract can improve the immune system to actively protect the body and improve the tissue after DMBA exposure [25].

$\mathrm{NF}-\alpha$ is cytotoxic for many types of tumor cells, and it is capable for triggering the cascade signal transduction, such as in the process of apoptosis, stimulating NF-kB, and the activation of p38 MAPK, ERK, JNK. The TNF- $\alpha$ attachment in TNFR1 will activate the TNFR-associated death domain (TRADD) as adapter proteins. This protein will interact with the cytopathic death domain on TNFR1 via death domain and activate the apoptosis process through the caspase pathway $[26,27]$. Therefore, we observed that TNF- $\alpha$ has a strong relationship with the level of tumors.

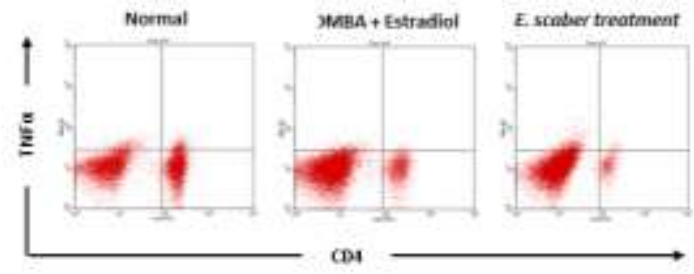

Figure 3. The relative number of $\mathrm{CD} 4^{+} \mathrm{TNF}-\alpha^{+} \mathrm{T}$ cell at the spleen organ

\section{Analysis the Number of CD4 ${ }^{+} \mathrm{IFN}-\boldsymbol{\gamma}^{+}$T Cells}

Proinflammatory cytokines such as IFN- $\gamma$ is a cytokine which expressed and synthesized by NK cells. Interferon also plays a role in increasing and inhibiting cell function. The inhibition function to reduce the normal cell growth and neoplastic cells. The function of enhancement addressed to kill bacteria by activating macrophages. The cytokines will activate macrophages in phagocytizing pathogens effectively. Also, the IFN- $\gamma$ cytokine will stimulate the response of some antibodies. IFN- $\gamma$ cytokines play a role in proinflammation and induction of type I immunity. The presence of these cytokines used to measure the immune system's work $[28,29]$.

Based on the experiment results, it showed that $E$. Scaber extract was significantly increased the relative number of $\mathrm{CD} 4^{+} \mathrm{IFN}-\gamma^{+}$cells $(\mathrm{p}<0.05)$ on the first week (15.16\%) and second (12.35\%) (Table 2). Healthy mice have a relative number of CD4 $4^{+}$IFN $-\gamma^{+}$cells that are not significantly different. It means that the relative number of CD $4^{+}$IFN $-\gamma^{+}$cells at week 1 , week 2 , and week 3 had the same results. When compared to DMBA and estradiol-induced mice, the healthy mice had a significant difference in the first week (5.99\%), second week $(1.13 \%)$, and the third week (2.20\%). However, in the first week, DMBA and estradiol-induced mice had a significantly higher number of cells $(p<0.05$ ) as compared to the second and third weeks. It demonstrated the self-recovery in mice after being injected with DMBA and estradiol on the first week.

Meanwhile, in the second and third weeks, there was a decreased number of $\mathrm{CD}^{+} \mathrm{IFN}-\gamma^{+}$ cells, which showed that there was no defense to inhibit the DMBA and estradiol carcinogens. The administration of $E$. Scaber extract also showed a significant decrease in every week. It means that in the first week, the number of IFN- $\gamma$ cytokines has increased to activate macrophages. Whereas, in the second and third weeks, there were a decreased IFN- $\gamma$ cytokines. It indicated that the $E$. scaber extract has not been able to maintain the amount of IFN- $\gamma$ because the carcinogen substance in the body of the mice increased.

However, as compared to the positive control group of mice exposed to DMBA and estradiol in the second week, it showed a significant increase $(12.35 \%)$. But, in the third week between the administration of DMBA and estradiol (2.20\%) and the administration of the extract, it did not show a significant difference (2.54\%) (Fig. 4). It explained that the carcinogen level in the mice's body could not be controlled by the immune system.

Under normal conditions, the body does not specifically respond to carcinogen agents so that the number of IFN- $\nu$ cytokines decreases. However, in the exposure to the DMBA and estrogen carcinogens, the body had self-recovery ability to fight the carcinogen. Treatment of $E$. 
Scaber extract can increase the amount of CD4 ${ }^{+}$IFN $-\gamma^{+}$to inhibit the carcinogenesis process in mice after induction of DMBA and estradiol [28]. IFN- $\nu$ activity is including the activation of macrophage cells and CTL in anti-tumors, increasing NK cell function as potent effector cells in lysis of cancer cells, and controlling the regulation of $B$ lymphocytes in the immune response. Activation of macrophages by IFN- $\gamma$ will secrete the activator cytokines, namely IFN- $\gamma$. This cytokine will activate the CTL cells and NK cells to kill cancer cells through the Fas-ligand pathway then activate FADD. The FADD activity will trigger the cascade activity to promote DNAse for the apoptosis process [30].

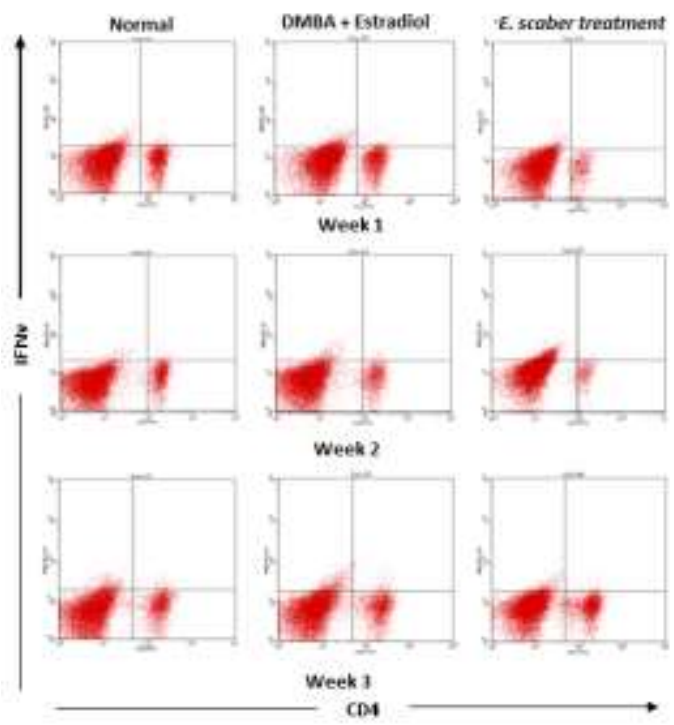

Figure 4. Percentage of relative number of $\mathrm{CD} 4^{+} \mathrm{IFN}-\gamma^{+} \mathrm{T}$ cell at the spleen organ

\section{CONCLUSION}

The results showed that the induction of DMBA and Estradiol carcinogens in mice had an effect of fur loss on mice. It also has an effect on decreasing the immune system through CD4 and CD8 T cells. However, the E. scaber extract can increase the number of proinflammatory cytokines of TNF- $\alpha$. Moreover, it also promoted the number of proinflammatory cytokines of $\mathrm{CD}^{+}{ }^{+} \mathrm{IFN}-\gamma^{+}$in the first week and decreased the number of $\mathrm{CD}^{+} \mathrm{IFN}-\gamma^{+}$in the second and third weeks. Then, it increased the number of $\mathrm{CD}^{+}$ TNF- $\alpha^{+}$. The treatment of $E$. scaber extract could increase the number of $C D 4^{+} I F N-\nu^{+}$in the first and second week. In brief, the treatment of E.scaber extract can restore the homeostasis of the immune system through the number of CD4 and CD8 T cells in the first and second week.

\section{REFERENCES}

[1] King, R.J.B. 2000. Cancer biology, $2^{\text {nd }}$ Ed. London School of Biological Sciences, University of Surrey. Guildford, UK

[2] World Health Organization. 2010. Cancer. Available at: http://www.who.int/.

[3] Evans, C., A.G. Dalgleish, D. Kumar. 2006. Immune Suppression and Colorectal Cancer. Aliment Pharmacol Ther. 24(8). 1163-1177.

[4] Lin, C.T., C.F. Hung, J. Juang, L. He, K.Y. Lin, T.W. Kim, et al. 2003. Boosting with recombinant vaccinia increases HPV-16 E7specific $T$ cell precursor frequencies and antitumor effects of HPV-16 E7-expressing Sindbis virus replicon particles. Mol. Ther. 8(4). 559-566.

[5] Kakizoe, T. 2003. Chemoprevention of cancer focusing on cinical trial, national cancer center, Jpn. J. Clin. Oncol. 33(9). 421442.

[6] Ren, W., Z. Qiao, H. Wang, L. Zhu, L. Zhang. 2003. Flavonoids: promising anticancer agents. Med. Res. Rev. 23(4). 519-534.

[7] Yong Ho, W., H. Ky, S.K. Yeap, R.A. Rahim, A.R. Omar, C. Ling Ho, N.B. Alitheen. 2009. Traditional practice, bioactivities and commercialization potential of Elephantopus scaber Linn. J. Med. Plants Res. 3(13). 1212-1221.

[8] Ichikawa, H., M.S. Nair, Y. Takada, D.B. Sheeja, M.A. Kumar, O.V. Oommen, B.B. Aggarwal. 2006. Isodeoxyelephantopin, a novel sesquiterpene lactone, potentiates apoptosis, inhibits invasion, and abolishes osteoclastogenesis through suppression of nuclear factor-kappaB (Nf-kappaB) activation and $\mathrm{Nf}$-kappaB regulated gene expression. Clin. Cancer Res. 12(19). 59105918.

[9] Dandekar, S., S. Sukumar, H. Zaebl, L.J.T. Young, R.D. Cardiff. 1986. Specific activation of the cellular Harvey-ras oncogene in DMBA-induced Mouse mammary tumors. Mol. Cell Biol. 6(11). 4104-4108.

[10] Roy, R.D., Md.S. Hossan, M. Rahmatullah. 2015. A Review of Anticancer Potential of Elephantopus scaber and Its Phytoconstituents. World J. Pharm. Pharmaceut.I Sci. 4(10). 86-94.

[11] Oluboyo AO, Meludu SC, Oyenekwe CC, Oluboyo, BO, Chianakwanam GU, Emegakor C. 2014. Assessment of immune stability in breast cancer subjects. Eur. Scien J. 10(27). 1857-7431. 
[12] Cheeke, P.R. 2000. Actual and potential applications of Yucca schidigera and Quuillaja saponaria saponins in human and animal nutrition. J. Anim. Sci. 77. 1-10.

[13] Marmi. 2010. Aktivitas Biologi Ekstrak Tapak Liman (Elephantopus scaber, L) Terhadap Perkembangan Limfosit Pada Mencit Balb/C. Master Thesis. Department of Biology, University of Brawijaya. Malang.

[14] Lai, Y.P., C.J. Jeng, S.C. Chen. 2011. The roles of $\mathrm{CD} 4+\mathrm{T}$ cells in tumor immunity. International Scholarly Research Network Immunology. 2011. 1-6.

[15] Brown, D.M. 2010. Cytolytic CD4 cells: direct mediators in infectious disease and malignancy. Cell. Immunol. 262(2). 89-95.

[16] Quezada, S.A., T.R.Simpson, K.S. Peggs, T. Merghoub, J. Vider, X. Fan, et al. 2010. Tumorreactive CD4+ $T$ cells develop cytotoxic activity and eradicate large established melanoma after transfer into lymphopenic hosts. J. Exp. Med. 207(3). 637-650.

[17] Kaech, S.M., E.J. Wherry, R. Ahmed. 2002. Effector and memory T-cell differentiation: implications for vaccine development. Nat. Rev. Immunol. 2(4). 251-262.

[18] Hung, C.F., W.F. Cheng, L. He, M. Ling, J. Juang, C.T. Lin, et al. 2003. Enhancing major histocompatibility complex class I antigen presentation by targeting antigen to centrosomes. Cancer Res. 63(10). 23932398.

[19] Djati, M.S., H. Habibu, N.A .Jatiatmaja, M. Rifai. 2015. Tapak liman (Elephantopus scaber L) extract induced CD4+ and CD8+ differentiation from hematopoietic stem cell/progenitor cell proliferation of mice (Mus musculus). J. Exp. Life Sci. 5(2). 97103.

[20] Rahimi, S., Z.T. Zadeh, M.A.K. Torshizi, R. Omidbaigi, H. Rokni. 2011. Effect of the three herbal extracts on growth performance, immune system, blood factors and intestinal selected bacterial population in broiler chickens. J. Agri. Tech. 13. 527- 539

[21] Mackey, M. F., R.J. Barth Jr., R.J. Noelle. 1998. The role of CD40/CD154 interactions in the priming, differentiation, and effector function of helper and cytotoxic T cells. $J$. Leukoc. Biol. 63(4). 418-428.

[22] Mackey, M.F., J.R.Gunn, P.P. Ting, et al. 1997. Protective immunity induced by tumor vaccines requires interaction between CD40 and its ligand, CD154. Cancer Res. 57(13). 2569-2574.

[23] Bourgeois, C., B. Rocha, C. Tanchot. 2002. A role for CD40 expression on CD8+ T cells in the generation of $\mathrm{CD} 8+\mathrm{T}$ cell memory. Science. 297(5589). 2060-2063.

[24] Shi, W., Q. Li, Z. Li. 2005. Comparison of anti-tumor affects between transmembrane and secretory tumor necrosis factor-alpha in vitro and in vivo. Mol. Ther. 11. doi:10.1016/j.ymthe.2005.06.294.

[25] Rahman, M. 2016. Aktivitas kemopreventif Ekstrak Temu Ireng (Curcuma aeruginosa Roxb) terhadap sel makrofag, IFN- $\gamma$ dan TNF- $\alpha$ tikus putih yang diinduksi 7,12Dimetilbenz[A]Antrasena. Master Thesis. Bogor Agricultural University. Bogor.

[26] Herbein, G., W.A. O'Brien. 2000. Tumor necrosis factor (TNF)- $\alpha$ and TNF receptors in viral pathogenesis. Proc. Soc. Exp. Biol. Med. 223(3). 241-257.

[27] Aggarwal, B.B., S.C. Gupta, J.H. Kim. 2012. Historical perspectives on tumor necrosis factor and its superfamily: 25 years later, a golden journey. Blood 119(3). 651-665.

[28] Abbas, A.K., A.H. Lichtman, S. Pillai. 2007. Cellular and Molecular Immunology, $6^{\text {th }} \mathrm{Ed}$. WB Saunders. USA.

[29] Lee, L.L., J.S.C. Lee, S.D. Waldman, R.F. Casper, M.D. Grynpas. 2002. Polycyclic aromatic hydrocarbons present in cigarette smoke cause bone loss in an ovariectomized rat model. Bone. 30. 917923.

[30] Ilyas, M. 2014. Pengaruh ekstrak etanol tumbuhan Cayratia trifolia L (Domin) terhadap peningkatan makrofag dan limfosit $T$ helper (CD4) pada tikus model kanker. Master Thesis. Airlangga University. Surabaya. 